\title{
Seasonal variation and Length-weight relationship of Clarias gariepinus from Oluwa River, Nigeria
}

\author{
*Ayandiran TA and Fawole OO \\ Pure and Applied Biology Department, LadokeAkintola University of Technology, Ogbomoso, Nigeria
}

\begin{abstract}
The length-weight relationship and seasonal abundance of the indigenous Clariasgariepinus from Oluwa River, Nigeria was evaluated. The total length and the weight of the fish ranged between $31.70-70.70 \mathrm{~cm}$

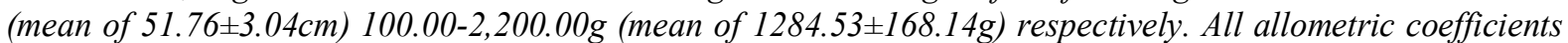
(b) for length-weight relationship showed isometry and negative allometry patterns. Correlation Coefficient ' $r$ ' between length and weight of males, female and both sexes for year 2010/2011 was 0.80, 0.28 and 0.63 respectively while that for year 2011/2012 was 0.30, 0.60 and 0.26 respectively. The Correlation Coefficient (r) for length-weight relationships (LWRs) was near unity (0.80) for males during the 2010/2011 season. Those of females and both sexes were far from one $(0.28$ and 0.63$)$ thus, did not show good length-weight relationship.Correlation Coefficient for LWRs was far from unity for males (0.30) and both sexes (0.26) while that of female was closer to one (0.60) for the second year. Males and both sexes did not show good fit to the line of regression and also did not show good relationship between the length-weight relationships in Clariasgariepinus in Oluwa River. This connotes that the fish species exhibited negative allometric growth pattern which may be caused by bitumen and other pollutants.
\end{abstract}

Keywords: Clariasgariepinus, Fisheries, Relationship, Season, Variation, Oluwa River.

\section{Introduction}

The length-weight relationship (LWR) is an important tool in fishery science,environmental assessments as well as management of water resources (Mendes et al., 2004; Zargaret al., 2012) as it describes the functional regime in weight distribution per unit size of an aquatic population. Hence, length-weight regressions have been used frequently for the estimation of weight from length because direct weight measurement has beenknown to be time consuming (Sinovcicet al., 2004). The length-weight values computed for various locations are useful for various ecological parameters of the water body which govern the dimensional variation exhibited by the inhabiting fish as part of adaptations to freshwater habitat.

Being an important factor in the biological study of fish, the Length-Weight relationship plays a significant role in the generation of parameters for yield equation and in the calculation of stock density and other important factorsin a water body (Abdurahimanet al., 2004; Ravi et al., 2012). In fish length-weight relationship studies, fish body weight has an exponential relationship with its length. The power function; $\mathrm{W}=$ $\mathrm{aL}^{\mathrm{b}}$ is used to represent the length-weight relationship (When, $\mathrm{W}=$ total weight of fish; $\mathrm{L}=$ total length; $\mathrm{a}=$ constant of proportionality; $b=$ allometry coefficient which most often fluctuates between 2 and 4). The exponent ' $b$ ' provides information on growth (Morey et al., 2003); being isometric when $b=3$ and allometric when this is not the case (positive if $\mathrm{b}>3$, negative if $\mathrm{b}<3$ ) (Mbaruet al., 2010).

In Nigeria, the fish yields of most inland waters are generally on the decline (Jamiu and Ayinla, 2003), which has been attributed to causes ranging from environmental degradation of the water bodies due to anthropogenic inputs from communities and industries. Deteriorating habitat quality has become a debatable question for ecologists and a significant research has been done on the relationship between deteriorating environmental quality and fish health status (Adams et al., 1993; Burke et al., 1993; Able et al., 1999). Researchers in the past have compared biological parameters in different water bodies having different trophic status in order to assess the influence of the environmental factors on fish growth. Tsoumaniet al.,(2006) compared the length-weight relationships of the cyprinid fish Carassiusgibelio in 12 commercially important lakes of Greece which differed in water quality and concluded that some of the factors (like phosphorus concentrations) may have impact on the ' $b$ ' value of length-weight relationship.

Previous studies on fish length- weight relationship in Africa have been carried out on large rivers (Welcome, 1976; Arawomo, 1987; Etim, 1993; Akpan, 1994; Fawole, 2002; Fawole and Adewoye, 2004; Benedict et al., 2009; Chukwu and Deekae, 2010). Few other studies on the LWR for fish species carriedout in otherregions includes in Algarve,Southern Portugal(Santos et al., 2002; Borgeset al., 2003) and along the Southwest coast of Portugal (Goncalveset al., 1997;Ismenet al., 2007; Özekinciet al., 2009; Torrez et al., 2012). Clariasgariepinusis widely accepted as a very suitable fish species in African aquaculture (Haylor, 1993). The distribution of Clariasspecies cuts across virtually all African countries and commands a very good commercial value in Nigerian market (Ayinlaet al., 1994; Fagbuaroet al., 2005). The fish constitutes a major fauna 
population of River Oluwa which is usually found in abundance during the rainy season more than the dry season. Prior to this research, the length-weight relationship, morphometric attributes among other useful parameters of fish living status in Oluwa River are yet to be quantified. The objective of this study is therefore to provide the first published data on the length-weight relationship of the indigenous Clariasgariepinus in River Oluwa, an economically important river in Ondo State, Nigeria.

\subsection{Study area}

\section{Materials And Methods}

River Oluwa in Agbabu is located on the Okitipupa South-East belt of the bituminous sands field at latitude $06^{0} 29$ " to $06^{\circ} 45^{\prime \prime}$ North and $04^{\circ} 44^{\prime \prime}$ to $05^{\circ} 00^{\prime \prime}$ East of the Greenwich Meridian. Agbabu bitumen belt is made of the main Agbabu village inhabited by about 1,600 people beside other settlements such as Temidire Village. Farmers in this area deal mainly in fishing along Oluwa River, which flows through the whole land. Some of those living in the villages and hamlets live on the shallow surface water of the river as source of portable water.The major pollutant of OluwaRiver besides domestic sources is bitumen seepage especially during the afternoon and mostly in the dry season when temperature is above $37^{\circ} \mathrm{C}$ during when the bitumen occurs as a free flowing liquid flowing into the River.

\subsection{Description of sampling Sites}

Two sampling Sites A and B $1 \mathrm{~km}$ apart were selected on Oluwa River. Site A is located upstream where there are high fishing activities and less domestic activities. Site B is located downstream where there are high domestic activities like bathing, swimming, washing of clothes and fetching the river water for drinking.

\subsection{Collection of fish samples}

Fishing was done during late night with the help of professional local fishermen. Gill nets about 12.192 $\mathrm{m}$ long and $1.828 \mathrm{~m}$ wide with a cork line at the top rope and metal line with the ground rope made locally of nylon were used for fishing. Two fishermen with the help of a wooden boat helped in the collection of fish samples from the two sampling Site. Fishing was done monthly over a two-year period starting from the month of July 2010 to June 2012. Samples were transported to the Ecotoxicology and fisheries Laboratory, LAUTECH in well aerated containers into which ice cubes were added to lower the temperature of the water before the commencement of further studies.

\subsection{Morphometric studies of fish}

Specie identification of the fish was done according to the FAO identification chart (Fischer and Bianchi, 1984). Monthly catches of C. gariepinus were subjected to morphometric studies. The morphometry included determination of body weight (live) body length, Standard length and total length. Measurements were done with length measuring boardand tape, while weight was taken using an electronic weighing balance after removal of excess water from the body surfaces.

The total length was measured from the tip of the Snout to the tip of the caudal fin while the standard length was taken from the tip of the snout to the base of the caudal fin.Length frequency distribution was also determined by plotting the frequency of occurrence throughout the sampling months against standard length, and represented with bar charts. Length-weight relationship was also determined by plotting Log of body weight against Log of standard length and it is expressed by the equation $\mathrm{W}=\mathrm{aL}^{\mathrm{b}}$

Where $\mathrm{W}=$ weight in grammes

$$
\begin{aligned}
& \mathrm{L}=\text { Length in centimeters } \\
& \mathrm{a}=\text { regression constant } \\
& \mathrm{b}=\text { an exponent lying between } 2 \text { and } 4
\end{aligned}
$$

This relationship can be transformed into a straight line relationship in the form.

$$
\log W=\log a+b \log L
$$

Where $b=$ regression coefficient (slope of the graph)

$\mathrm{a}=\quad$ regression constant (intercept of the regression line on the $\mathrm{Y}$ axis).

\subsection{Size Distribution}

\section{Result}

The river of study and its tributaries is shown in figure 1. A total number of 293 specimens of Clariasgariepinus were collected during the study period. Peak mean weight was observed in April 2011 while the least mean weight was observed in July 2012 (Figure 2). Out of the 293 fish sampled, 151 were collected between July 2010 and June 2011, making $51.53 \%$ of the total specimen collected. A total number of $142 \mathrm{C}$. gariepinus were collected between July 2011 and June, 2012 with a percentage of $48.40 \%$ of the total specimen number. 
The total length of the fish sampled throughout the study period ranged between $31.70-70.70 \mathrm{~cm}$ with a mean value of $51.76 \pm 3.04 \mathrm{~cm}$ (Table 1). The weight of the fish ranged from $100.00-2,200.00 \mathrm{~g}$ with a mean value of $1284.53 \pm 168.14 \mathrm{~g}$ (Table 1). The length-frequency distribution of C. gariepinus, harvested throughout the sampling period in Oluwa River is represented in figure 2 . The study revealed that a wide range of sizes were harvested throughout the study period. The size range with the highest occurrence was $43.00-45.90 \mathrm{~cm}$. Bimodal size range distribution was observed at size range of $34.00-36.90 \mathrm{~cm}, 52.00-54.90 \mathrm{~cm}, 49.00-51.90 \mathrm{~cm}$, $58.00-60.90 \mathrm{~cm}$ and $61.00-63.90 \mathrm{~cm}$ (Figure 3). The length- frequency distribution of male and female Clariasgariepinus sampled throughout the study period is represented in figure 3. Males had a clear mode at $37.00-39.90 \mathrm{~cm}$ (MTL) while females dominated the $43.00-45.90 \mathrm{~cm}$ and $46.00-48.90 \mathrm{~cm}$ (MTL).

\subsection{Length-Weight Relationship}

The length-weight equation model established for males, females and both sexes of C. gariepinus is given in Table 2. The regression model fitted for length and weight of the fish under study is given in figures5a to $5 f$.

First Year (July 2010- July 2011)

MALES $\log \mathrm{W}=-1.585+2.705 \log \mathrm{L}(\mathrm{n}=70, \mathrm{R}=0.80)$

FEMALES $\operatorname{LogW}=2.51+0.354 \operatorname{LogL}(\mathrm{n}=81, \mathrm{R}=0.28)$

BOTH SEXES $\log \mathrm{W}=1.85+0.66 \operatorname{LogL}(\mathrm{n}=151, \mathrm{R}=0.63)$

Second Year (July 2011- June 2012)

MALES $\log \mathrm{W}=2.52+0.202 \operatorname{LogL}(\mathrm{n}=78, \mathrm{R}=0.30)$

FEMALES $\quad \log \mathrm{W}=-1.709+2.790 \log \mathrm{L}(\mathrm{n}=64, \mathrm{R}=0.60)$

BOTH SEXES $\log \mathrm{W}=\quad-1.045+0.290 \log \mathrm{L}(\mathrm{n}=142, \mathrm{R}=0.26)$

All allometric coefficients (b) for length-weight relationship estimated in this study showed isometry and negative allometry growth patterns. For fishes which maintain dimensional equality, the isometric value will be 3 (Benedict et al., 2009).

Regression Coefficient (b) larger or smaller than 3.0, shows an allometric growth (Bagenal and Tesch, 1978). When value ' $b$ ' is greater than 3 , it is said to have a positive allometric growth. However, ' $b$ ' value less than 3 shows a negative allometric growth.

Correlation Coefficient ' $r$ ' between length and weight of males, female and both sexes for 2010/2011 was $0.80,0.28$ and 0.63 respectively. Correlation Coefficient ' $r$ ' between length and weight of males, female and both sexes for 2011/2012 was 0.30, 0.60 and 0.26 respectively (Table 2).

The Correlation Coefficient (r) for length-weight relationships (LWRs) was close to unity $(0.80)$ for males during the 2010/2011 season of the study. This shows a good fit to the line of regression showing good relationship between length and weight in males. Those of females and both sexes were far from one $(0.28$ and 0.63 ) thus, did not show good length-weight relationship (Table 2).

Correlation Coefficient for LWRs was far from unity for males (0.30) and both sexes $(0.26)$ while that of female was closer to one (0.60) for the second year. Males and both sexes did not show good fit to the line of regression and also did not show good relationship between the length-weight relationships in Clariasgariepinus in Oluwa River.

\section{Discussion}

This study showed that Clariasgariepinus of various size ranges exist in Oluwa River. The fish species with the size range of $43.00-45.90 \mathrm{~cm}$ were most abundant, followed by $37.00-39.90 \mathrm{~cm}$ and $46.00-48.90 \mathrm{~cm}$ with a percentage frequency of $13.31 \%, 12.28 \%$ and $11.94 \%$ respectively. This revealed that a wide range of sizes of the species is found in Oluwa River. This observation conformed to the submission of Fawole and Adewoye, (2004), who observed size range of $26.00-28.90 \mathrm{~cm}$ and $32.0-34.90 \mathrm{~cm}$ to be most abundant for Clariasgariepinus in Oba reservoir, an indication that a wide range of sizes of the fish species was found in Oba reservoir.

Seasonally, there are more fish specimens harvested during the dry season than the rainy season, with $47.09 \%$ of the total catch in rainy season while $52.90 \%$ of the total catch in dry season. The higher catch recorded in the dry season could be as a result of the fish species being benthic feeders and also because of the great reduction in the water volume during the dry season. The reduction in water volume will definitely reduce the available space of escape from cast and gill nets as well as traps used in catching the fish species.

However, more fish species were sampled during the first year of the study (July, 2010- June, 2011) while there was a reduction in the population of the fish sampled in the second year (July, 2011- June, 2012). This may be as a result of the seepage of bitumen in the river which could be on the increase yearly. Another factor could be as a result of the anthropogenic activities of villagers on the river. 
The length-weight relationship of Clariasgariepinus in Oluwa River reflected a linear growth, indicating the three dimensional growth structures of most fish species. Similar result was obtained by Torrez et al., (2012) for 76 different fish species in Spain. The result also agrees with the report of Mata et al., (2008). The regression coefficient ' $b$ ' recorded for male specimen for the first year of study (July, 2010 - June, 2011) is approximately 3 indicating that males exhibit isometric growth in Oluwa River. For fishes which maintain dimensional equality, the isometric value is usually 3 (Benedict et al., 2009). Regression coefficient (b), larger or smaller than 3.0, shows an allometric growth (Bagenal and Tesch, 1978).

Furthermore, the isometric growth observed in this study for males in the first year of this study indicated that the male Clariasgariepinus did not increase in weight faster than the cube of their total length.

Females exhibited very low regression coefficient in the first year of the study. The regression coefficient exhibited by the females was negative allometry. This implied that the female fish species may be increasing in length faster than its weight or the weight of the fish increased faster than the cube of their total lengths. Similar trend as in females was observed for the combined sexes.

However, results obtained for length-weight relationship for the second year revealed that males exhibited negative allometric coefficient growth pattern while females exhibited regression coefficient ' $b$ ' values that is approximately 3 , this implies that females exhibited isometric growth. For the combined sexes, very low ' $b$ ' values were obtained which implies negative allometry. This result agrees with the submission of (Chukwu and Deekae, 2010) that length-weight relationship are indicative of isometric and allometric growths in which some differ not only between sexes but sometimes also between stocks of the same species.

The growth pattern observed in this study corroborated with the opinion of Fawole and Adewoye (2004) that obtained ' $b$ ' values of 2.485, 2.486 and 2.286 for males, females and combined sexes of Clariasgariepinus respectively in Oba reservoir, Ogbomoso. The result obtained from the regression coefficient (b) of the fish species is also in consonance with the report of David et al.,(2010) who observed that male Clariasgariepinusexhibited higher ' $b$ ' values than females and the growth pattern was isometric for males and allometric for females; a similar trend observed in this first year of this study.

Furthermore, it has been well established that the development of fish involves several stages each of which has its own length-weight relationship. There may also be differences in the relationships due to many factors such as sex, temperature, salinity, food, habitat, pollution level, maturity, season and among others (Froeze, 2006; Olurin and Aderibigbe, 2006). This statement could be a possible reason for the growth pattern observed inClariasgariepinus in Oluwa River throughout the sampling period.

It is also known that regression coefficient (b) value represents the body form, and it is directly related to the weight affected by ecological factors such as temperature, food supply, spawning conditions and other factors, such as sex, age, fishing time and area as well as fishing vessel (Stergion, 2002; Froese, 2006 and Ferhat, 2007).However, the correlation regression ' $r$ ' between length and weight for male $\mathrm{C}$. gariepinus in the first year of the study revealed that the value was closer to unity. This means that the relationship between length and weight of male C. gariepinus is high, as the length of the fish increases, the weight also increased. Female fish specimen however showed very low correlation regression between length and weight which is farther from 1(unity), while for the combined sexes the value was not close to 1 . Female fish species could therefore be said to have very poor correlation between the length and weight of the fish species which implied that as the fish weight is increasing it is not increasing in length in the same proportion.

For the second year however, there was a good correlation between length and weight of the female C. gariepinus whereas males had low correlation between the length and weight. For the combined sexes, the correlation was also not close to one which connotes low correlation between length and weight of the fish species. This result however conformed to the submissions of David et al.,(2010). The reason for the differences in the correlation regression could be as a result of the Bitumen seepage and other pollutants constant entering Oluwa River and imparting negatively on the fish growth pattern.

\section{Conclusion}

Fishes (C. gariepinus) harvested from Oluwa River exhibited negative allometric growth pattern which implies that fish species is increasing in length faster than its weight or vice versa which could be due to the polluted nature of the river which might have altered the growth pattern/ processes of the fish species.

\section{Acknowledgement}

The authors wishes to thank the staff and laboratory workers of the Ecotoxicology laboratory of the Department of Pure and Applied Department, LAUTECH, Ogbomoso, Nigeria for their efforts during the course of this work. 


\section{References}

[1]. Abdurahiman KP, Harishnayak T, Zacharia PU, Mohamed KS. 2004. Length-weight relationship of commercially important marine fishes and shellfishes of the Southern coast of Karnataka, India. NAGA World Fish Cent.Quartenary27(1 \& 2): 9-14.

[2]. Able KW, Manderson JP,Studholme AL. 1999. Habitat quality for shallow water fishes in urban estuary: the effect of man-made structures on growth. Marine Ecology 187: 227-235.

[3]. Adams SM, Brown AM,Goede RW. 1993. A quantitative health assessment index for rapid evaluation of fish condition in the field. Transactionof the American Fisheries Society 122: 63-73.

[4]. Akpan ER. 1994. Dynamics in the length-weight relationship and condition index of three species of Pseudotolithus(Pisces: Sciaenidae) in three tropical river estuaries. Livingand Sustainable Development 2(5): 33-44.

[5]. ArawomoGAO. 1987. The fish fauna of the rivers in the Federal Capital Territory, Abuja Nigeria. Ife Journal of Science 2(1): 3445.

[6]. Ayinla OA, Kayode O, Idoniboye-Obu TIE, Oresegun A, Adindu VE. 1994. Use of tadpole meal as a substitute for fishmeal in the diet of Heterobranchusbidorsalis (Geofrey St. Hillaire, 1809). Journal of Aquaculturefor the Tropics 9(1): 25-33.

[7]. Bagenal TB,Tesch FW. 1978. Age and growth of fish in Methods for Assessment of fish production in Freshwaters. (Ed. Ricker, W.E.). Blackwell Scientific Publication. Oxford, London.364pp.

[8]. Benedict O, Offem YAS, Isaac TO. 2009. Length-weight Relationship, Condition Factor and Sex Ratio of Forty Six Important Fishes in a Tropical Flood River. Research in Fisheries and Hydrobiology 4(2): 65-72.

[9]. Borges TC, Olim S, Erzini K. 2003. Weight-length relationships for fish species discarded in commercial fisheries of the Algarve (southern Portugal). Journal of Applied Ichthyology 19, 394-396.

[10]. Burke JS, Peters DS, Hanson PJ. 1993. Morphological indices and otolith microstructure of Atlantic croaker, Micropogoniasundalatus, as indicators of habitat quality along an estuarine pollution gradient.Environmental Biologyof Fishes 36 : 25-33.

[11]. Chukwu KO,Deekae SN. 2010. Length-weight relationship, condition factor and size composition of Periophthalmus barbarous (Linneaus 1766) in New Calabar River, Nigeria. Agriculture and Biological Journal of North America2(7): 1069 -1071.

[12]. David DL, Edward A,Addass PA, Jesse C. 2010. Some aspects of Water Quality and the Biology of Clariasgariepinusin Vimtim Stream, Mubi Adamawa State, Nigeria.World Journalof Fisheriesand Marine Science 2(2): 129 -133.

[13]. Etim L. 1993. Seasonal variation in tissue weight and biochemical composition of Egeriaradiate (Tellinacea: Donacidae) from Cross River, Nigeria. Tropical Ecology 34(2): 30.

[14]. Fawole OO. 2002. Morphometric and diet of Mormyrusrumein the Lekki lagoon, Nigeria. Review of Biologyfor the Tropics50(2): 689-694.

[15]. Fawole OO,Adewoye SO. 2004. Aspect of the biology of Clariasgariepinus (Burchell, 1822) in Oba reservoir, Ogbomoso, Nigeria. ScienceFocus 8: 96-100.

[16]. Ferhat K, Necati S, Sabri B, Osman S. 2007. Length-weight relationship of 10 fish species caught by bottom trawl and midwater trawl from the middle black sea, Turkey.

[17]. Fischer W, Bianchi G, Lobsters. In: Danish International Development Agency (DANIDA). Western Indian Ocean (Fishing Area 51). Rome: Food and Agricultural Organization of the United Nations; 1984.

[18]. Froese R. 2006. Cube law, condition factor and weight- length relationships: history, meta-analysis and recommendations. Journal of Applied Ichthyology 22: 241-253.

[19]. Goncalves JMS, Bentes L, Lino PG, Ribeiro J, Canario AVM, Erzini K. 1997. Weight-length relationships for selected fish species of the small-scale demersal fisheries of the south and south-west coast of Portugal.Fisheries Research 30: $253-256$.

[20]. HaylorA. 1993. Aspects of the fish Biology of the African catfish C. gariepinus in recent advances in Aquaculture.Vol.1. HetchtUjosot South African National Science programme. Report No., 153.

[21]. Ismen A, Ozen O, Altinagac U, Ozekinci U, Ayaz A. 2007. Weight-length relationships

[22]. Jamiu, D.M., Ayinla, O.A., 2003. "Potential for the Development of Aquaculture in Africa" NAGA, 693: 9-13.

[23]. Mata AJ, Morales J, Márquez L. 2008. Weight-length relationships for 26 demersal fish species of the Spanish South-Atlantic coastal waters. Journal of Applied Ichthyology 24: 330-333.

[24]. Mbarua EK, Mlewa CM, Kimania EN. 2010 Length-weight relationship of 39 selected reef fishes in the Kenyan coastal artisanal fishery. Fisheries Research 106: 567-569

[25]. Mendes B, Fonseca P, Campos A. 2004. Weight-length relationships for 46 fish species of the Portuguese west coast. Journal of Applied Ichthyology 20: 355-361.

[26]. Morey G, Moranta J, Massut E, Grau A, Linde M, Riera F, Morales-Nin B. 2003. Weight-length relationships of littoral to lower slope fishes from the western Mediterranean.Fisheries Research 62: 89-96.

[27]. Olurin KB, Aderibigbe A. 2006. Length-weight relationship and condition factor of pond reared juvenile Oreochromisniloticus. World Journal of Zoology 1(21): $82-85$.

[28]. Özekinci U, Cengiz Ö, Ismen A, Altinagac U, Ayaz A. 2009. Length-weight relationships of thirteen flatfishes (Pisces: Pleuronectiformes) from Saroz Bay (North Aegean Sea, Turkey). Journal of Animaland Veterinary Advances 8: $1800-1801$.

[29]. RaviV, Sekar V, Kesavan K. 2012.Length-weight relationship and morphometrics of the sailfish, Istiophorusplatypterus(Shaw \&Nodder) from Parangipettai, Southeast coast of India.Asian Pacific Journalof Tropical Biomedicine S373-S376

[30]. Santos MN, Gaspar MB, Vasconcelos P, Monteiro CC. 2002. Weight-length relationshipsfor 50 selected fish species of the Algarve (southern Portugal). Fisheries Research 59: 289-295.

[31]. Slnovcic G, FranicevicM,ZoricaB, Clles-KeeV. 2004. Length- weight and length-length

[32]. relationship of 10 pelagic fish species from Adriatic Sea (Croatia).Journalof AppliedIchthiology 20: $156-167$.

[33]. Stergiou KI, Moutopoulos DK. 2001. A review of length-weight relationships of fishes from Greek Marine Waters.ICLARM Quartenary. 24 (1-2): 23-39.

[34]. TorresMA, RamosF, Sobrino I. 2012. Length-weight relationships of 76 fish species from the Gulf of Cadiz (SW Spain). Fisheries Research 127- 128: $171-175$

[35]. Tsoumani M, Liasko R, Moutsaki P, Kagalou I,Leonardos I. 2006. Length-weight relationships of an invasive cyprinid fish (Carassiusgibelio) from 12 Greek lakes in relation to their trophic states.Journalof Applied Ichthyology 22: $281-284$.

[36]. Welcome RL. 1976. Extensive aqua-cultural practices in African flood plains. CIFA Tech Paper. 14(1): 248-255.

[37]. Zargar UR, Yousuf BM, Dilafroza J. 2012. Length-weight relationship of the Crucian carp, Carassiuscarrassuis in relation to water quality, sex and season in some lenthic water bodies of Kashmir Himlayas.Turkish Journalof Fisheriesand Aquatic Science 12: 683689. 
Table 1: Frequency of occurrence and mean Length-weightrelationship of Clariasgariepinus from Oluwa

\begin{tabular}{llll}
\multicolumn{5}{c}{ River } \\
\cline { 2 - 4 } TLR & Frequency & MTL (cm) & Mean weight (g) \\
\hline $31.00-33.90$ & 12 & $32.71 \pm 0.17$ & $342.50 \pm 47.42$ \\
$34.00-36.90$ & 25 & $35.60 \pm 0.17$ & $503.20 \pm 57.79$ \\
$37.00-39.90$ & 36 & $38.40 \pm 0.12$ & $658.89 \pm 32.87$ \\
$40.00-42.90$ & 31 & $41.16 \pm 0.14$ & $689.03 \pm 32.66$ \\
$43.00-45.90$ & 39 & $44.05 \pm 0.14$ & $807.44 \pm 45.20$ \\
$46.00-48.90$ & 35 & $47.73 \pm 0.15$ & $1064.29 \pm 61.24$ \\
$49.00-51.90$ & 15 & $50.01 \pm 0.20$ & $1142.67 \pm 95.63$ \\
$52.00-54.90$ & 25 & $53.24 \pm 0.17$ & $1255.60 \pm 61.39$ \\
$55.00-57.90$ & 20 & $56.48 \pm 0.19$ & $1663.00 \pm 58.41$ \\
$58.00-60.90$ & 15 & $59.02 \pm 0.20$ & $1707.00 \pm 94.16$ \\
$61.00-63.90$ & 15 & $62.52 \pm 0.23$ & $1976.67 \pm 64.61$ \\
$64.00-66.90$ & 14 & $65.24 \pm 0.25$ & $1981.43 \pm 61.79$ \\
$67.00-69.90$ & 08 & $68.14 \pm 0.29$ & $2125.00 \pm 75.00$ \\
$70.00-72.90$ & 03 & $70.47 \pm 0.12$ & $2066.67 \pm 66.67$ \\
Total & & $51.76 \pm 3.04$ & $1284.53 \pm 168.14$ \\
\hline \multicolumn{4}{c}{ MTL $=$ Mean totallength } \\
\hline
\end{tabular}

Table 2: Length-Weight relationship of Clariasgariepinus collected from Oluwa River

\begin{tabular}{|c|c|c|c|c|c|c|c|c|}
\hline Year & Sex & $\mathbf{N}$ & $\mathbf{R}$ & Equation $\mathrm{W}=\mathrm{aL}^{\mathrm{b}}$ & S.E (b) & A & B & Growth type \\
\hline \multirow[t]{3}{*}{$2010 / 2011$} & Male & 70 & 0.80 & $\mathrm{~W}=-1.585 \mathrm{~L}^{2.705}$ & 0.246 & -1.585 & 2.705 & Isometric \\
\hline & Female & 81 & 0.28 & $\mathrm{~W}=2.510 \mathrm{~L}^{0.354}$ & 0.134 & 2.510 & 0.354 & Allometric (-) \\
\hline & Both sexes & 151 & 0.63 & $\mathrm{~W}=1.850 \mathrm{~L}^{0.663}$ & 0.126 & 1.850 & 0.663 & Allometric (-) \\
\hline \multirow[t]{3}{*}{$2011 / 2012$} & Male & 78 & 0.30 & $\mathrm{~W}=2.520 \mathrm{~L}^{0.202}$ & 0.074 & 2.520 & 0.202 & Allometric (-) \\
\hline & Female & 64 & 0.60 & $\mathrm{~W}=-1.709 \mathrm{~L}^{2.790}$ & 0.444 & -1.709 & 2.790 & Isometric \\
\hline & Both sexes & 142 & 0.26 & $\mathrm{~W}=-1.045 \mathrm{~L}^{0.290}$ & 0.090 & -1.045 & 0.290 & Allometric (-) \\
\hline
\end{tabular}

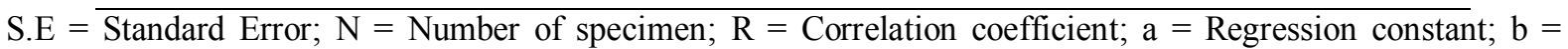
Regression coefficient

$\mathrm{L}=$ Total length.

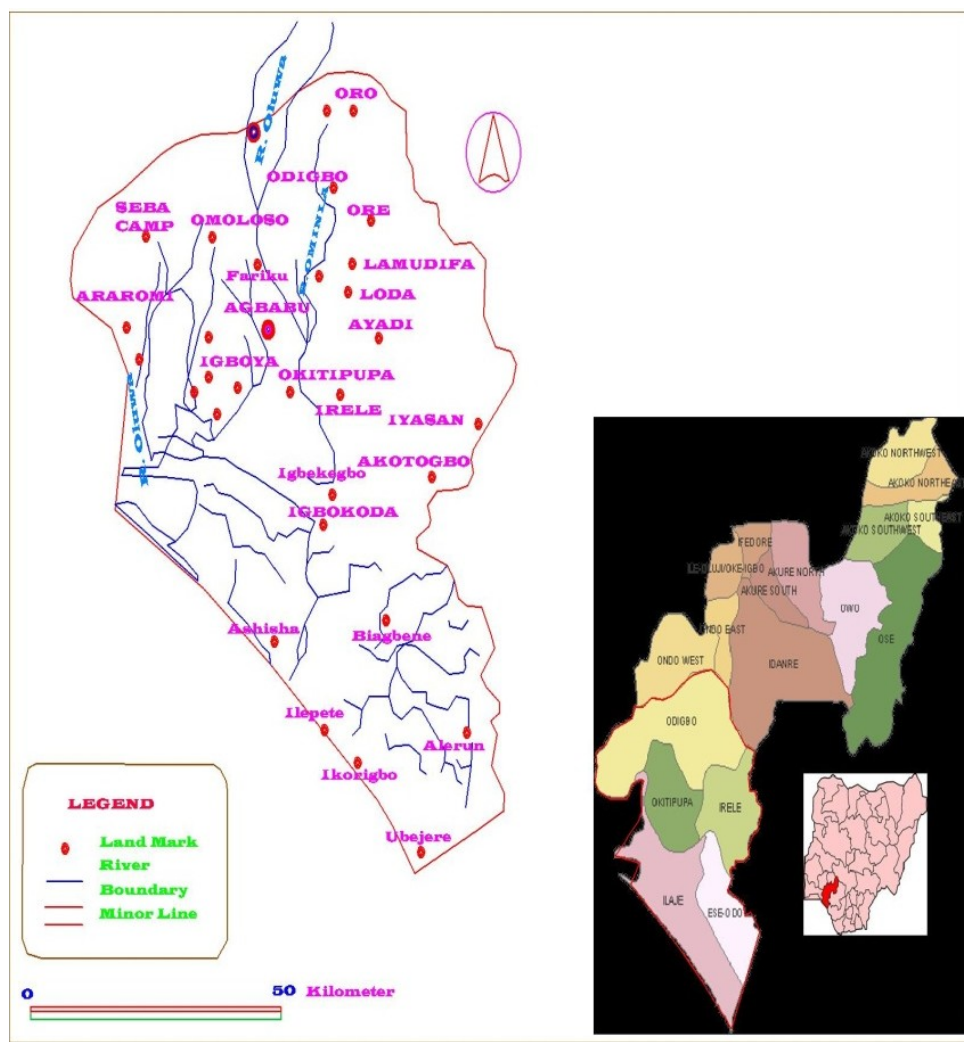

Figure 1: Map of study area 


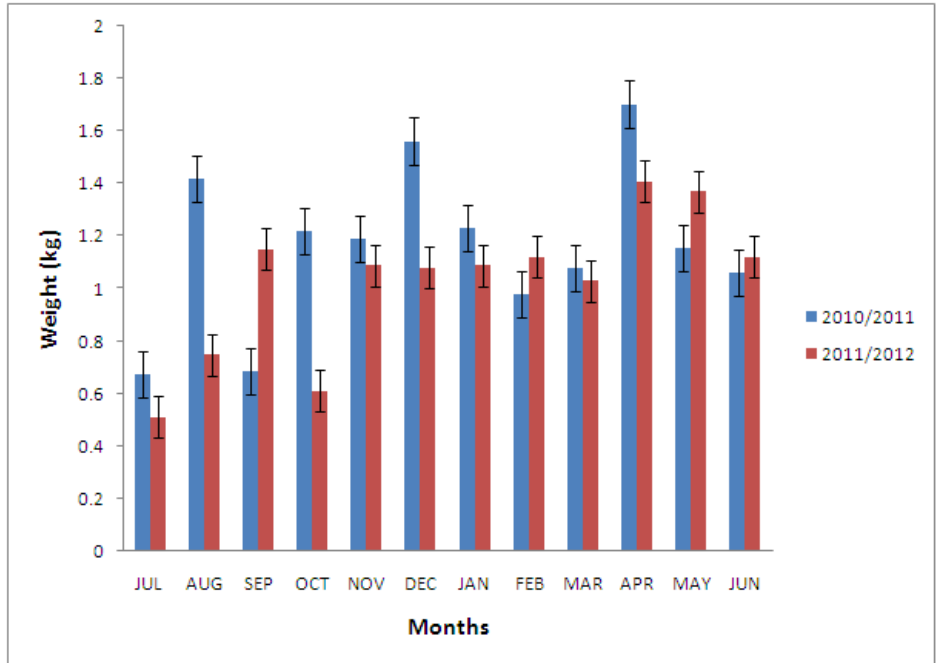

Figure 2: Variation in seasonal abundance of Clariasgariepinus from Oluwa River

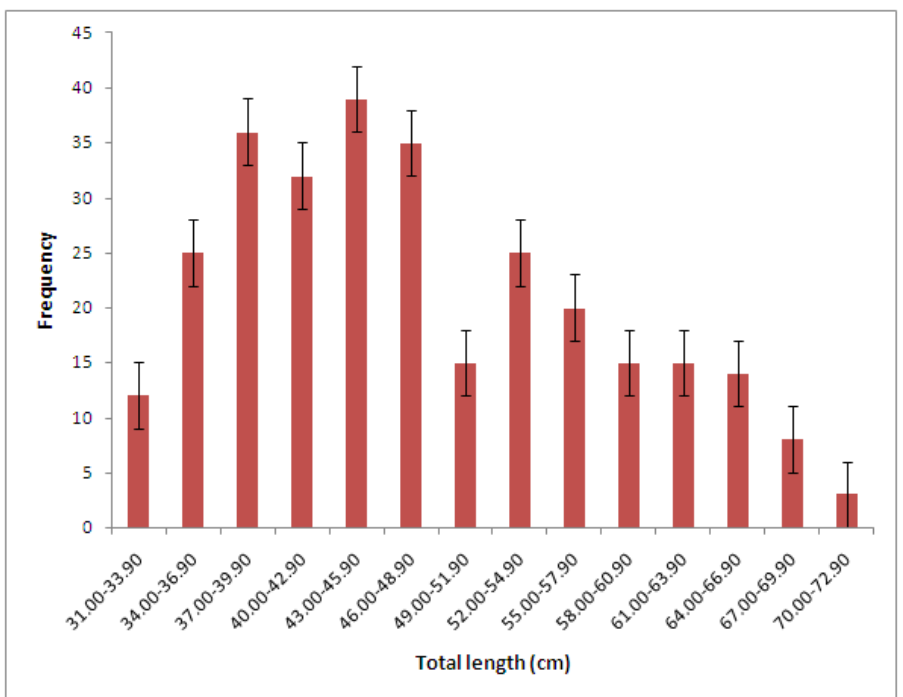

Figure 3: Length-frequency distribution of Clariasgariepinus from Oluwa River

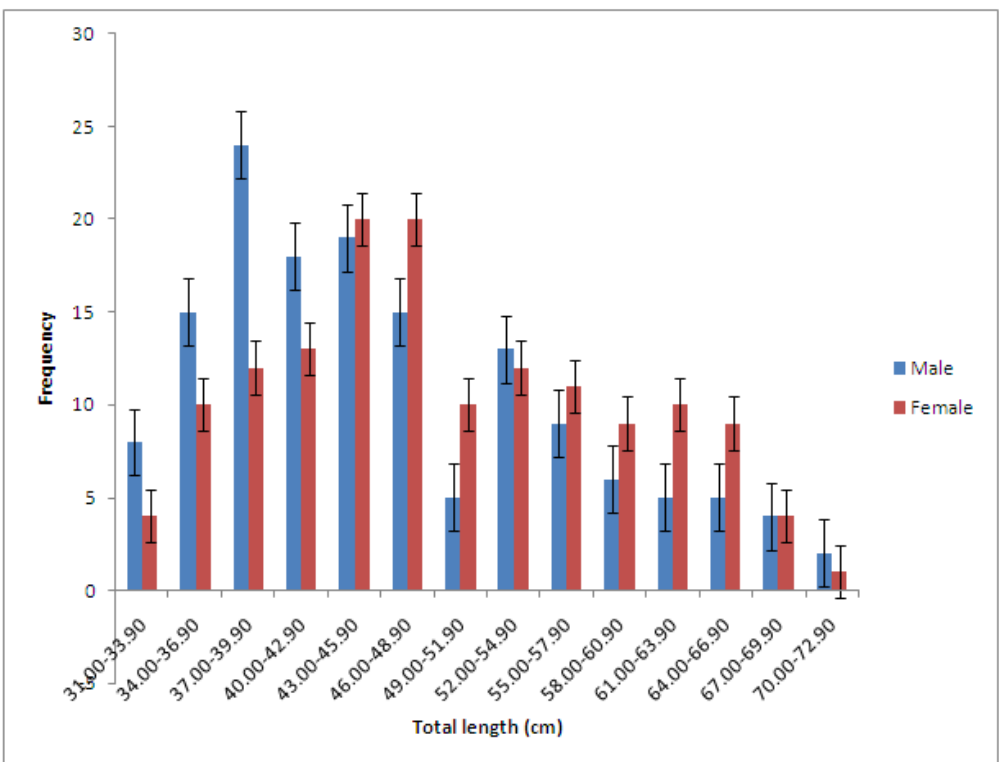

Figure 4: Length-frequency distribution of male and female Clariasgariepinus from Oluwa River 


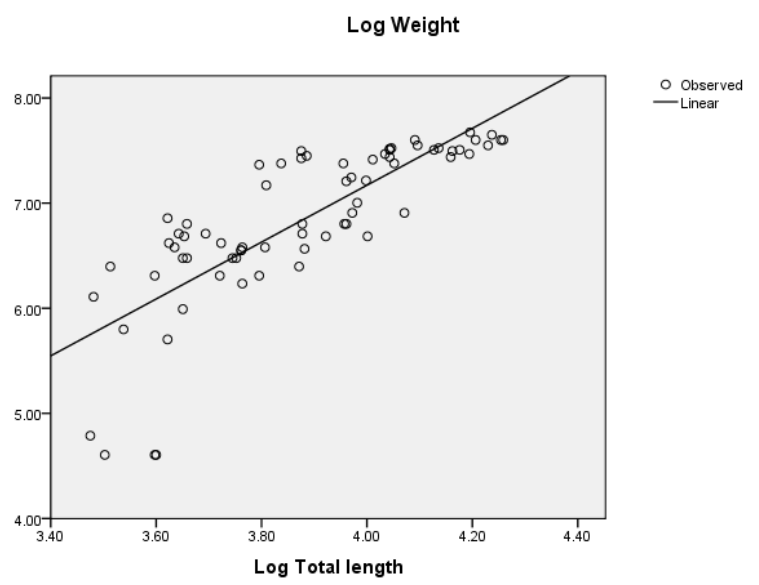

$\mathbf{R}=\mathbf{0 . 8 0}$

Figure 5a: Linear Relationship between Log of Body weight and Log of total Length of Male Clariasgariepinus from Oluwa River (2010/2011).

Log Weight

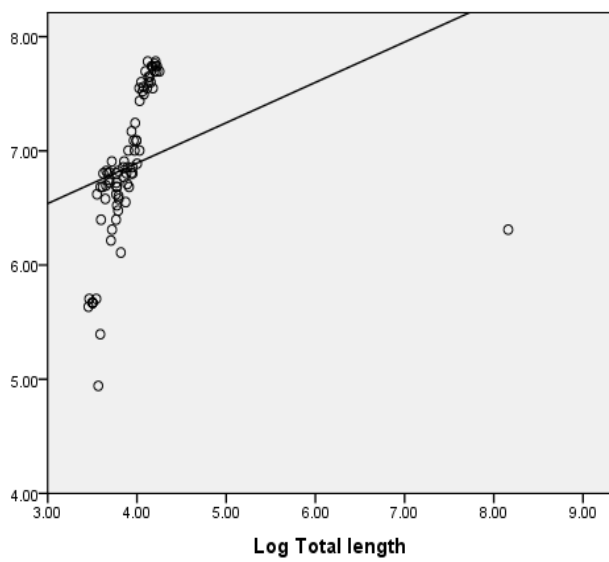

- Observed

$\mathbf{R}=\mathbf{0 . 2 8}$

Figure 5b: Linear Relationship between Log of Body weight and Log of total Length of Female Clariasgariepinus from Oluwa River (2010/2011).

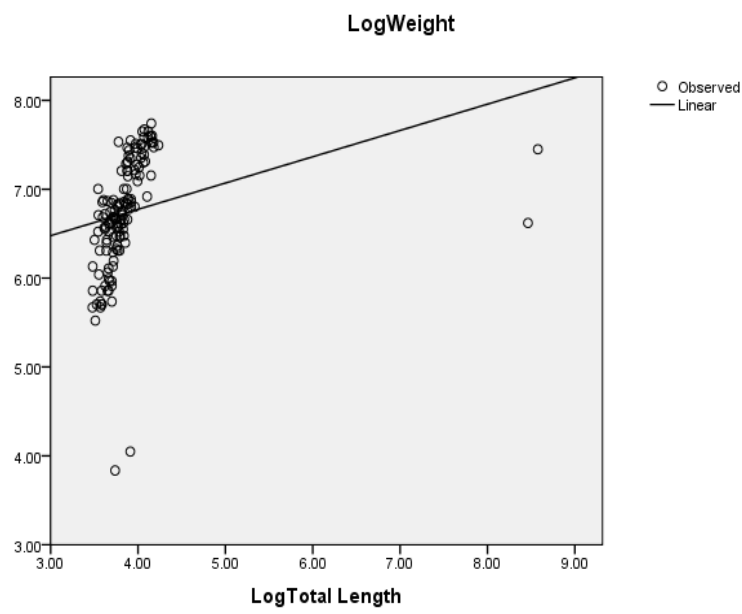

$R=0.63$

Figure 5c: Linear Relationship between Log of body weight and Log of total Length of Combined sexes of Clariasgariepinus from Oluwa River (2010/2011). 


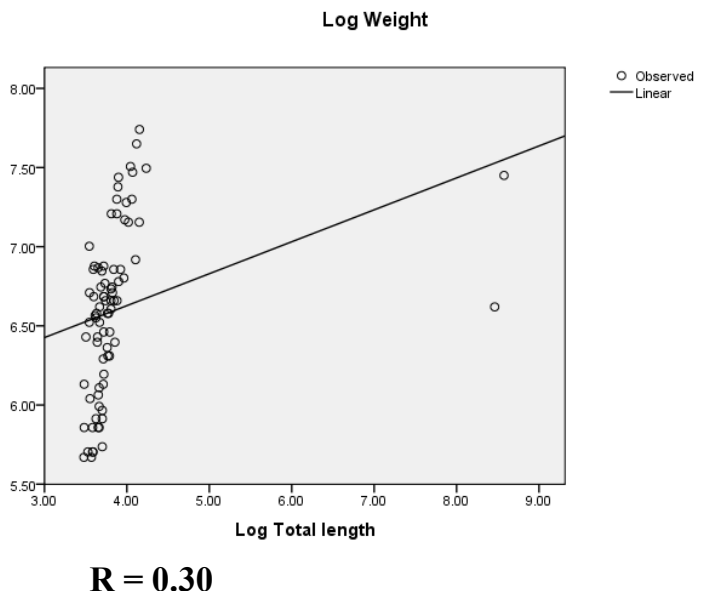

Figure 5d: Linear Relationship between Log of body weight and Log of total Length of Male Clariasgariepinus from Oluwa River (2011/2012).

Log Weight

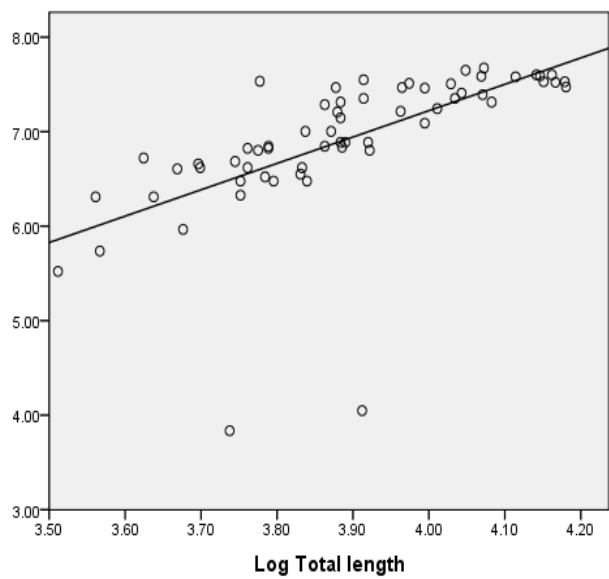

$\underset{\text { — Observed }}{\text { Linear }}$

$\mathbf{R}=\mathbf{0 . 6 0}$

Figure 5e: Linear Relationship between Log of body weight and Log of total Length of Female Clariasgariepinus from Oluwa River (2011/2012).

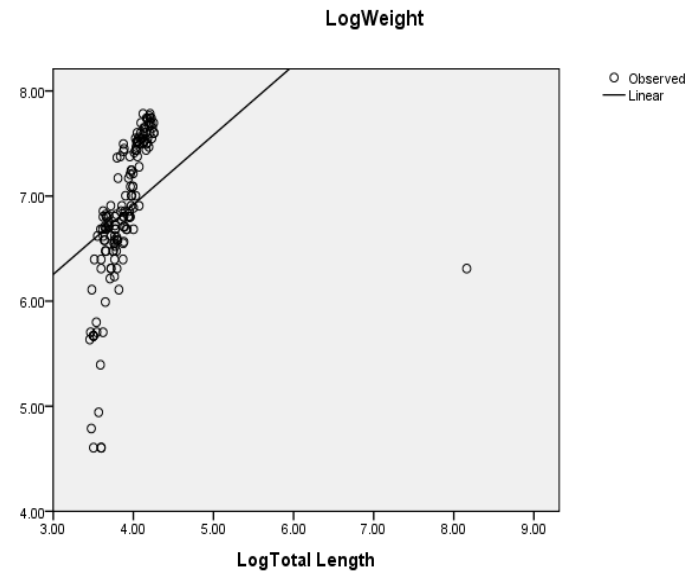

$\mathbf{R}=\mathbf{0 . 2 6}$

Figure 5f: Linear Relationship between Log of body weight and Log of total Length of Combined sexes of Clariasgariepinus from Oluwa River (2011/2012). 